\title{
PENGARUH BAURAN PEMASARAN TERHADAP KOMUNIKASI DARI MULUT KE MULUT MELALUI KEPUASAN PELANGGAN
}

\author{
Nurhadi Wijayanto \\ PT. JAMSOSTEK (Persero) Kantor Cabang Pasuruan \\ E-mail:Nurhadi_wijayanto@yahoo.com
}

\begin{abstract}
This research represent quantitative research and it aims to analyse influence of marketing mix to word of mouth with customer satisfaction as intervening variable. By using two way of that is enquette method and of interview. The tool of analyses used Structural Equation Modelling (SEM). Result of research indicate that marketing mix which consist of product, price, place, promotion, people, physical evidence and process influenced to customer satisfaction at participant of program of Jamsostek. In detail, those product variables namely price, place, promotion, and physical evidence have influenced significantly to customer satisfaction where as people variable and process did not influence significantly to customer satisfaction. The Customer satisfaction have influenced to word of mouth (WOM) at participant of program of Jamsostek. Marketing mix (product, price, place, promotion, people, physical evidence and process) have influence to word of mouth (WOM). Marketing mix did not influence to word of mouth (WOM) directly but indirect influence to WOM. It mean that the customer satisfaction did not have synergy with marketing mix.
\end{abstract}

Keyword: Marketing mix, customer satisfaction, word of mouth.

\section{PENDAHULUAN}

Penggunaan bauran pemasaran dalam pemasaran diharapkan konsumen mendapat apa yang diinginkan, sehingga akan tercipta suatu kepuasan setelah melakukan pembelian. Kepuasan konsumen dipengaruhi oleh persepsi kualitasjasa, kualitas produk, harga dan faktor-faktor yang bersifat pribadi serta bersifat situasi sesaat (Rangkuti, 2003). Artinya kepuasan dapat dirasakan ketika produk dan pelayanan yang diberikan melebihi dari apa yang diharapkan sehingga mereka akan bercerita dan berkomunikasi dengan orang lain tentang apa yang dia rasakan. Komunikasi WOM merupakan sumber penting berkenaan dengan informasi pelanggan. Itu membentuk dasar dari komunikasi antar personal dan secara signifikan mempengaruhi penilaian produk atau jasa dan keputusan untuk menggunakan produk atau jasa itu kembali (Mahajan, dkk, 1990).
Hal ini tidak terlepas bahwa WOM dipandang lebih kredibel dan selalu relevan sepanjang masa, dikendalikan oleh keputusan pelanggan, pada umumnya tumbuh secara eksponensial. Misalnya seseorang bercerita pada lima orang, kemudian mereka masing-masing menceritakan pada lima orang pula atau bahkan lebih. WOM ini juga memunculkan sifat manusia dalam memberikan atau menceritakan fakta pada seseorang layaknya mereka adalah seorang ahli (Jerram, 2003).

WOM antar pelanggan yang muncul secara alami dan jujur merupakan efek yang diinginkan oleh perusahaan, dan ini diakui oleh semua pakar marketing bahwa pesan pemasaran yang dihasilkannyapun lebih jauh efektif di banding dengan media lain. Ketika isi pesan WOM itu jujur, maka setiap orang akan menganggapnya sebagai sesuatu yang menyenangkan dan tidak akan menimbulkan kerugian sehingga mendorong diri mereka untuk layak menceritakan kepada orang lain. Bahkan 
terkadang mendesak orang lain yang mereka temui agar lebih cepat membeli produk-merk yang secara nyata bernilai. WOM semakin kuat ketika terjadi dalam suatu mutual dialogue. Dalam praktek pemasaran, cara kerja word of mouth marketing menggunakan sentuhan one to one person alized yang kemudian pesan itu menyebar bagaikan virus (viral) sehingga menjadi heboh (buzz), hal ini juga terjadi pada peserta program Jamsostek.

Suatu strategi pemasaran atau informasi yang jelas seperti tersebut di atas pasti akan menjadi dasar yang baik untuk menjalin hubungan yang harmonis antara perusahaan dengan peserta, hal ini secara tidak langsung akan membentuk suatu rekomendasi dari mulut ke mulut (word of mouth) pada diri peserta terhadap lingkunganya sehingga akan berakibat menguntungkan bagi perusahaan. Berdasarkan pemikiran tersebut, dilakukan penelitian mengenai Pengaruh Bauran Pemasaran Jasa terhadap Komunikasi dari Mulut ke Mulut melalui Kepuasan Pelanggan. Tujuan penelitian ini untuk menganalisis dan mengkaji pengaruh bauran pemasaran (7P) yang terdiri dari produk, harga, tempat, promosi, orang, proses dan bukti fisik terhadap kepuasan pelanggan pada peserta program Jamsostek.

Selain itu juga bertujuan untuk menganalisis dan mengkaji pengaruh kepuasan pelanggan terhadap komunikasi dari mulut ke mulut, untuk menganalisis dan mengkaji pengaruh bauran pemasaran (7P) yang terdiri dari produk, harga, tempat, promosi, orang, proses dan bukti fisik terhadap komunikasi dari mulut ke mulut pada peserta program Jamsostek, serta untuk menganalisis dan mengkaji pengaruh bauran pemasaran (7P) yang terdiri dari produk, harga, tempat, promosi, orang, proses dan bukti fisik terhadap komunikasi dari mulut ke mulut apabila melalui kepuasan pelanggan.

PT. Jamsostek (Persero) merupakan Badan Usaha Milik Negara (BUMN) yang pada hakekatnya memberikan perlindungan bagi tenaga kerja beserta keluarganya dalam menghadapi resiko sosial tertentu seperti terjadi peristiwa kecelakaan yang berhubungan dengan pekerjaan, sakit, hamil, berkurangnya penghasilan (usia lanjut/hari tua) serta meninggal dunia. Sesuai dengan Undang-undang
No.3 Tahun 1992 menyelenggarakan 4 program meliputi: 1. Jaminan Kecelakaan Kerja (JKK), 2. Jaminan Kematian (JK), 3. Jaminan Hari Tua (JHT) dan 4. Jaminan Pemeliharaan Kesehatan (JPK). Sebagai badan penyelenggara program Jaminan Sosial Tenaga Kerja, meskipun sudah di lengkapi dengan peraturan perundangan yang ada harus tetap mengedepankan keprofesionalisme dalam hal pemberian pelayanan kepada peserta Jamsostek, sehingga diperlukan suatu strategi informasi atau pemasaran dalam mensosialisasikan produk/program yang di milikinya seperti manfaat program jamsostek, kemudahan proses pengajuan klaim, pelayanan dari petugas yang ramah dan selalu dapat memenuhi apa yang sudah di janjikan kepada peserta Jamsostek.

\section{TINJAUANPUSTAKA}

Bauran pemasaran merupakan alat (tool) bagi marketer yang terbagi dalam elemen program pemasaran yang perlu diperhatikan agar implementasi strategi pemasaran dan positioning dapat berjalan dengan sukses (Lupiyoadi, 2001). Menurut Assauri (1999) bauran pemasaran merupakan kombinasi variabel atau kegiatan yang merupakan inti dari sistim pemasaran, variabel mana yang dapat dikendalikan oleh perusahaan untuk mengetahui reaksi para pembeli atau konsumen. Ada empat unsur variabel bauran pemasaran yaitu: produk (product), harga (price), promosi (promotion) dan lokasi (place). Yazid (2003) mengungkapkan bahwa bauran pemasaran jasa terdiri dari 4P ditambah 3P. elemen - elemen yang bisa dikontrol dan dikoordinasikan untuk keperluan komunikasi dalam memuaskan konsumen jasa tersebut adalah (1)Produk (Product), (2) Harga (price), (3) Promosi (Promotion), (4) Lokasi (place), (5) Orang (people), (6) Proses (process), (7) Bukti Fisik (Physical evidence).

Selanjutnya Zeithaml dan Bitner (2000) mengemukakan konsep bauran pemasaran tradisional (traditional marketing mix) terdiri dari 4P, yaitu: Produk (Product), Harga (price), Lokasi /tempat (Place), dan Promosi (Promotion). Sementara itu, untuk pemasaran jasa perlu bauran 
pemasaran yang di perluas (expanded marketing mix for service) dengan penambahan unsur non-traditional marketing mix, yaitu: People(orang), Process (proses) dan Physical Evidence (bukti fisik), sehingga menjadi unsur (7P). Masing-masing dari tujuh unsur bauran pemasaran tersebut saling berhubungan sehingga secara optimal sesuai dengan karakteristik segmennya.

Uraian tersebut menjelaskan bahwa jasa diproduksi secara simultan dengan konsumsinya dan jasa lebih banyak unsur intangible, maka konsumen sering mencari tanda-tanda yang tangibleuntuk membantu memahami karakteristik jasa, dalam penelitian ini bauran pemasaran jasa yang digunakan adalah bauran pemasaran yang terdiri dari 7P, sebagai berikut: (1) Produk (prod$u c t$ ), (2) Harga (price), (3) Promosi (promotion), (4) Lokasi (place), (5) Orang (people), (6) Proses (process), (7) Bukti Fisik (Physical evidence).

\section{Word Of Mouth (WOM)}

Komunikasi adalah suatu hal yang esensial dalam kehidupan manusia. Melalui komunikasi manusia dapat saling bertukar pikiran untuk membangun pengertian. Selain itu komunisi dapat mempengaruhi peikiran dan tingkah laku, seperti komunikasi yang digunakan dalam word of mouth.

Beach (1995) dalam bukunya menyatakan bahwa komunikasi berfungsi untuk mendorong dan mengarahkan manusia untuk melakukan sesuatu, dan komunikasi membantu membentuk sikap dan menanamkan kepercayaan untuk mengajak, meyakinkan dan mempengaruhi perilaku. Pada masyarakat model word of mouth telah sejak lama digunakan dimana prinsipnya agar berita, pemberitahuan, undangan, dan informasi lainnya dapat disampaikan secara meluas dari mulut kemulut secara lisan atau dalam bahasa jawanya gethok tular.

Hasan (2010) mengungkapkan bahwa word of mouthadalah tindakan konsumen memberikan informasi kepada konsumen lain dari seseorang kepada orang lain (antar pribadi) non komersial baik merek, produk maupun jasa. Sejalan dengan hal itu, Assael (1998) mendefinisikan bahwa Word of mouth adalah komunikasi interpersonal antara dua bahkan lebih individu seperti anggota kelompok referensi atau konsumen dan tenaga penjual. Rekomendasi dari mulut ke mulut merupakan salah satu faktor penting yang berpengaruh terhadap keputusan seseorang dalam membeli suatu produk.

Assel (1998) mengatakan "A satisfied customer is your best sales person". Ilustrasi ini menggambarkan petingnya word of mouth untuk kepuasan pelanggan atas pengaruh teman dan secara relatif akan memberi ketidakpuasan konsumen sehingga akan menghalangi penjualan. Menurut Carl (2005) terdapat dua bentuk WOM, yaitu 1) organic atau natural WOM, 2) amplified WOM. Dalam teknik word of mouth marketing yang diarahkan untuk mendorong orang berbicara satu sama lain tentang produk atau jasa adalah yang pertama Buzz Marketingyaitu menggunakan high profile berita untuk mendapatkan orang untuk berbicara tentang merk, kedua Viral Marketing yaitu menciptakan masukan pesan informatif yang di rancang untuk dapat diteruskan dalam model eksponensial seperti melalui e-mail, selanjutnya Community Marketing dimana pembentukan atau mendukung ceruk komunitas yang mungkin untuk berbagi kepentingan tentang merek untuk mendukung suatu komunitas, keempat adalah Grassroots Marketing, yakni Pengorganisasian dan memotivasi relawan untuk engagepribadi atau jangkauan local, kemudian Evangelist Marketingyaitu Merekrut pendukung baru, advokasi, atau relawan yang didorong untuk mengambil peran leadershipdalam menyebarkan pesan secara aktif, selanjutnya Influencer Marketingyaitu Mengidentifikasi masyarakat dan pendapat kunci lcadersyang cenderung berbicara tentang produk dan memiliki kemampuan untuk influence pendapat orang lain, ketujuh adalah Street Marketingyaitu menjangkau dan berinteraksi dengan konsumen secara langsung di suatu tempat secara berkala, delapan Stealth-undercover Markeing, yaitu Gerakan marketing di bawah ambang sadar, misalnya menggunakan seorang aktor untuk menyebarkan pesan positif dari satu brandkepada public, sembilan Causc Marketing, yakni Pendukung yang merasa sangat tahu tentang penyebabnya sehingga akan selalu mensupport, sepuluh Prod- 
uct Seedingadalah Meletakan yang benar produk ke tangan kanan di waktu yang tepat dan menyediakan informasi atau sampel untuk individu yang berpengaruh, sebelas Conversation Creation yaitu Menarik atau menyenangkan iklan, hiburan atau promosi dirancang untuk memulai aktifitas mulut, kemudian Brand Bloggingyaitu Menciptakan blog dan berpartisipasi dalam bloging, dalam semangat terbuka, trans-orang tua komunikasi dan berbagi informasi nilai, dan yang terakhir adalah Referral Programsyaitu Membuat alat yang memungkinkan pelanggan puas melihat teman-teman mereka.

\section{Kepuasan Pelanggan}

Secara sederhana kepuasan dapat diartikan sebagai ungkapan seorang pengguna jasa yang merasakan produk suatu perusahaan. Seperti yang diungkapkan beberapa pakar yang memberikan definisi mengenai kepuasan pelanggan. Menurut Day (dalam Tjiptono, 2002) menyatakan bahwa kepuasan atau ketidakpuasan pelanggan adalah respon pelanggan terhadap evaluasi ketidaksesuaian atau diskonfirmasi yang dirasakan antara harapan sebelumnya.

Menurut Engel, et al (1990) mengungkapkan bahwa kepuasan pelanggan merupakan evaluasi purnabeli di mana alternatif yang dipilih sekurangkurangnya memberikan hasil (outcome) sama atau melampaui harapan pelanggan, sedangkan ketidakpuasan timbul apabila hasil yang diperoleh tidak memenuhi harapan pelanggan. Sedangkan menurut Kotler (1994) mengatakan bahwa kepuasan pelanggan adalah tingkat perasaan seseorang setelah membandingkan kinerja (atau hasil) yang ia rasakan dibandingkan dengan harapannya.

Bila ditelaah terdapat kesamaan diantara beberapa definisi di atas, yaitu menyangkut komponen kepuasan pelanggan (harapan dan kinerja atau hasil yang dirasakan). Secara konseptual, kepuasan pelanggan dapat dilihat seperti yang ditunjukkan dalam gambar 1 .

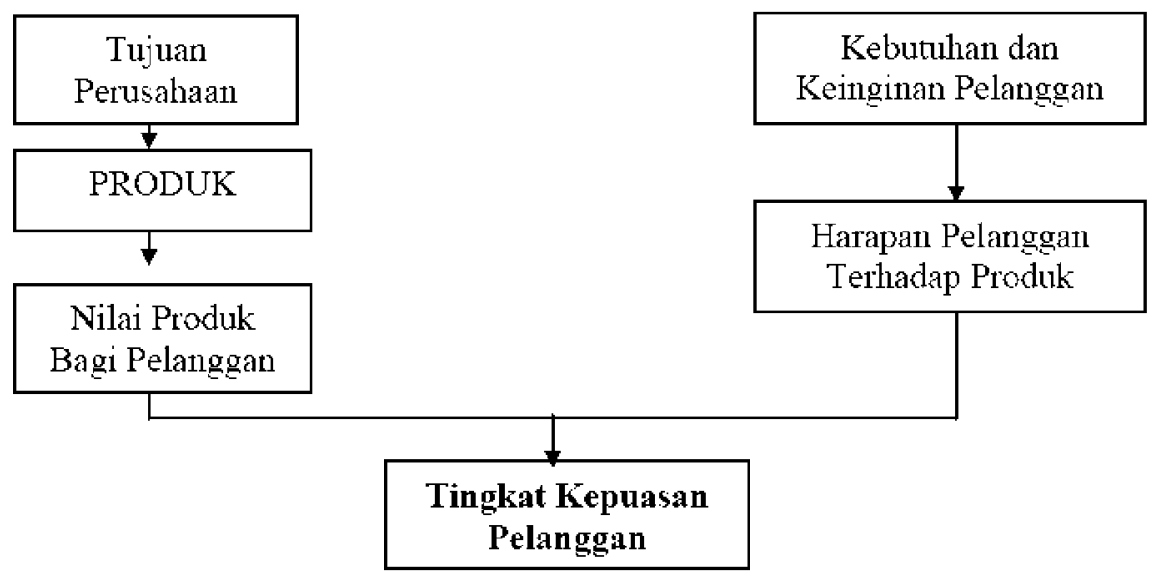

Gambar 1 Konsep Kepuasan Pelanggan

Berdasarkan beberapa definisi di atas dapat disimpulkan bahwa kepuasan pelanggan terdiri dari dua unsur yaitu mencakup perbedaan antara harapan dan kinerja atau hasil yang dirasakan. Jadi kepuasan pelanggan yang dimaksud di sini adalah harapan pelanggan terhadap program-program yang disampaikan oleh PT.Jamsostek (persero) dibandingkan dengan kinerja pelayanan yang dirasakan oleh peserta.

\section{METODE PENELITIAN}

Penelitian ini dapat digolongkan kedalam penelitian kuantitatif, karena data yang akan dibu- 
tuhkan adalah data berupa angka-angka atau data dalam bentuk informasi, komentar, pendapat atau kalimat yang nantinya akan dikuantitatifkan (diubah dalam bentuk angka), diolah dengan menggunakan rumus statistik tertentu, dan diinterpretasikan.

Penelitian ini di lakukan di wilayah kerja operasional PT. JAMSOSTEK (Persero) Cabang Pasuruan dengan jumlah populasi sebanyak 1.146 perusahaan dan sampel yang di ambil sebanyak 115 responden. Analisis data dalam penelitian ini menggunakan Structural Equation Modelling (SEM) yang bersumber dari data primer yaitu berupa jawaban kuisioner dari responden.

\section{HASIL PENELITIAN DAN PEMBAHASAN}

Hasil penelitian menunjukan bahwa karakteristik responden sebagian besar laki-laki dibandingkan dengan perempuan, usia responden seba- gian besar diatas 35, tingkat pendidikan sebagian besar Sarjana (S1) dan masa kerja sebagaian besar diatas 11 tahun. Hal ini memberikan penjelasan bahwa laki-laki menjadi tulang punggung keluarga sehingga pada umumnya memiliki tanggung jawab yang lebih besar di bandingkan dengan para wanita, usia di atas 35 tahun pada umumnya memiliki cukup ketrampilan dan pengalaman yang memadai sehingga keberadaanya di perhitungkan dan di pertimbangkan oleh perusahaan, tingkat pendidikan formal merupakan ukuran daya saing dan kompetisi di dunia kerja agar mampu melaksanakan tugas yang di berikan oleh perusahaan dan masa kerja bisa menjadi indikator loyalitas (senioritas) terhadap di suatu perusahaan sehingga dapat di simpulkan sebagaian besar berpengalaman dalam bekerja

Dalam uji kesesuaian model dan cut-off valuenya di terima atau di tolak sebuah model dapat di lihat pada tabel dibawah ini.

Tabel 1: Indeks Kelayakan Model

\begin{tabular}{clcc}
\hline No & \multicolumn{1}{c}{ GOODNESS OF FIT INDEX } & Nilai & CUT-OF POINT \\
\hline 1. & X $^{2-}$ Chi Square & 550.902 & di harapkan kecil \\
2. & Probability & 0,074 & $\geq 0,05$ \\
3. & RMSEA (the Root Mean Square Error of Approximation) & 0,039 & $\leq 0,08$ \\
4. & GFI (good of Fit Index) & 0,824 & $\geq 0,90$ \\
5. & AGFI (Adjusted Goodness of Fit Indices) & 0,778 & $\geq 0,90$ \\
6. & CMIN/DF (The Minimum Sample Discrepancy Function) & 1,22 & $\leq 2,00$ \\
7. & TLI (Tackler Lewis Index) & 0,95 & $\geq 0,95$ \\
8. & CFI (Comparative Fit Index) & 9,64 & $\geq 0,94$ \\
\hline
\end{tabular}

Analisis hasil pengujian goodness - of fit index menunjukkan data mempunyai kecocokan yang baik dengan model penelitian yaitu dengan hasil evaluasi Chi Square550.902, dengan tingkat non signifikansi 0,074 dan nilai RMSEA $(0,039)$, CMIN/df (1,122), TLI $(0,95)$, CFI $(9,64)$ walaupun hasil GFI $(0,824)$ dan AGFI $(0,778)$ yang masih berada dibawah cut off value namun sudah dapat dikatakan bahwa model sudah fit. Model menunjukkan bahwa pengaruh variabel Bauran Pema- saran (Produk, Harga, Tempat, Promosi, Orang, Proses, Bukti Fisik) terhadap Komunikasi dari Mulut ke Mulut melalui variabel Kepuasan Pelanggan, memberikan pengaruh yang signifikan. Sementara itu Kepuasan Pelangganberpengaruh langsung terhadap Komunikasi dari Mulut ke Mulut (WOM) Besarnya nilai $\mathrm{R}^{2}$ dalam hal ini ditunjukkan oleh nilai AGFI sebesar 0,778, hal itu menunjukkan secara keseluruhan variabel bauran pemasaran, menerangkan $77,8 \%$ varian dalam 
Komunikasi dari Mulut ke Mulut, dan 22,2 \% diterangkan oleh variabel lain di luar penelitian ini yang tidak dimasukkan dalam model.

Hasil analisis SEM yang dilakukan terhadap model yang dikembangkan dalam penelitian ini adalah Pengaruh bauran pemasaran terhadap kepuasan pelanggan. Salah satu tujuan dari penelitian ini adalah untuk menganalisis dan mengkaji pengaruh Bauran Pemasaran yang terdiri dari (produk, Harga, Promosi, Tempat, Orang, proses dan Bukti Fisik) terhadap Kepuasan Pelangganpada peserta program Jamsostek. Untuk mempermudah pembahasan atas analisis yang dilakukan, akan dijelaskan pengaruh dari masing-masing variabel bebas yang meliputi produk, harga, promosi,tempat, orang, proses dan bukti fisik terhadap kepuasan pelanggan.

Kemudian Pengaruh Produk Terhadap kepuasan pelanggan. Hasil pengujian pengaruh langsung produk terhadap kepuasan pelanggan secara statistik menunjukkan hasil yang signifikan. Hal itu ditunjukkan oleh nilai CR sebesar 2.798 dan probabilitas signifikansi $(p)=0,0005<\alpha=$ 0,05 mengindikasikan bahwa pengaruhnya signifikan. Maka hipotesis yang menyatakan bahwa produk berpengaruh langsung dan signifikan terhadap kepuasan pelanggan diterima. Besarnya nilai estimasi sebesar 0,374 menunjukkan besarnya perubahan kepuasan pelanggan (Y1) yang disebabkan oleh perubahan variabel produk (X1) dengan asumsi variabel yang lain konstan. Lebih lanjut dapat dijelaskan bahwa hasil tersebut di atas sejalan dengan apa yang diungkapkan olehAssauri $(1999 ; 181)$, produk adalah barang atau jasa yang dihasilkan untuk digunakan oleh pelanggan guna memenuhi kebutuhan dan memberikan keputusannya.

Hasil pengujian pengaruh langsung harga terhadap kepuasan pelanggan secara statistik menunjukkan hasil yang signifikan. Hal itu ditunjukkan oleh nilai CR sebesar 2.825 dan probabilitas signifikansi $(p)=0,0005<\alpha=0,05$ mengindikasikan bahwa pengaruhnya signifikan, maka hipotesis yang menyatakan bahwa harga berpengaruh langsung dan signifikan terhadap kepuasan pelanggan diterima. Besarnya nilai estimasi sebesar 0,598 menunjukkan besarnya perubahan kepuasan pelanggan (Y1) yang disebabkan oleh perubahan variabel harga (X2) dengan asumsi variabel yang lain konstan. Sehingga variabel harga menjadi salah satu faktor penentu untuk menjadi peserta Jamsostek. Hal ini sejalan pula dengan penelitian yang dilakukan oleh Johannes, Mulyadi Raf, M. Lukman di tahun 2006 bertujuan untuk mengetahui kepuasan nasabah berdasarkan bauran pemasaran yaitu bauran pemasaran yang salah satunya mengandung unsur harga memberikan pengaruh yang signifikan atau berarti terhadap kepuasan pelanggan.

Kemudian hasil pengujian pengaruh langsung tempat terhadap kepuasan pelanggan secara statistik menunjukkan hasil yang signifikan. Hal itu ditunjukkan oleh nilai CR sebesar 2.294 dan probabilitas signifikansi $(p)=0,022<\mathrm{a}=0,05$ mengindikasikan bahwa pengaruhnya signifikan. Maka hipotesis yang menyatakan bahwa tempat berpengaruh langsung dan signifikan terhadap kepuasan pelanggan diterima. Besarnya nilai

Tabel 2 Ringkasan Perhitungan bauran pemasaran terhadap kepuasan pelanggan

\begin{tabular}{lcllllc}
\hline & & & Estimate & S.E. & C.R. & P \\
\hline Kepuasan Pelanggan (Y1) & $\leftarrow$ & Produk (X1) & 0.374 & 0.134 & 2.798 & 0.005 \\
Kepuasan Pelanggan (Y1) & $\leftarrow$ & Harga (X2) & 0.598 & 0.212 & 2.825 & 0.005 \\
Kepuasan Pelanggan (Y1) & $\leftarrow$ & Tempat (X3) & 0.299 & 0.13 & 2.294 & 0.022 \\
Kepuasan Pelanggan (Y1) & $\leftarrow$ & Promosi (X4) & 0.323 & 0.362 & 2.393 & 0.017 \\
Kepuasan Pelanggan (Y1) & $\leftarrow$ & Orang (X5) & 0.079 & 0.092 & 0.857 & 0.391 \\
Kepuasan Pelanggan (Y1) & $\leftarrow$ & Proses (X6) & -0.382 & 0.254 & -1.503 & 0.133 \\
Kepuasan Pelanggan (Y1) & $\leftarrow$ & Bukti Fisik (X7) & 0.294 & 0.096 & 3.077 & 0.002 \\
\hline
\end{tabular}


estimasi sebesar 0,229 menunjukkan besarnya perubahan kepuasan pelanggan (Y1) yang disebabkan oleh perubahan variabel tempat (X3) dengan asumsi variabel yang lain konstan. Hasil tersebut memberikan penjelasan bahwa tempat juga menjadi pertimbangan untuk menjadi peserta Jamsostek. Hal ini sejalan dengan penelitian yang dilakukan oleh Johannes, Mulyadi Raf, M. Lukman di tahun 2006. Artinya bauran pemasaran yang salah satunya mengandung unsur tempat memberikan pengaruh yang signifikan atau berarti terhadap kepuasan pelanggan.

Pengaruh langsung promosi terhadap kepuasan pelanggansecara statistik menunjukkan hasil yang signifikan. Hal itu ditunjukkan oleh nilai CR sebesar 2.393 dan probabilitas signifikansi $(p)$ $=0,017<\alpha=0,05$ mengindikasikan bahwa pengaruhnya signifikan. Maka hipotesis yang menyatakan bahwa promosiberpengaruh langsung dan signifikan terhadap kepuasan pelanggan diterima. Besarnya nilai estimasi sebesar 0,323 menunjukkan besarnya perubahan kepuasan pelanggan (Y1) yang disebabkan oleh perubahan variabel promosi (X4) dengan asumsi variabel yang lain konstan. Hasil tersebut memberikan penjelasan bahwa promosi memberikan peranan dalam mempengaruhi kepuasan pelanggan, hal ini sejalan pula dengan penelitian yang dilakukan oleh Johannes, Mulyadi Raf, M. Lukman di tahun 2006. Artinya bauran pemasaran yang salah satunya mengandung unsur promosi memberikan pengaruh yang signifikan atau berarti terhadap kepuasan pelanggan.

Hasil pengujian pengaruh langsung orang terhadap kepuasan pelanggan secara statistik menunjukkan hasil yang tidak signifikan. Hal itu ditunjukkan oleh nilai CR sebesar 0.857 dan probabilitas signifikansi $(p)=0,391>\alpha=0,05$ mengindikasikan bahwa pengaruhnya tidak signifikan. Dengan demikian hipotesis yang menyatakan bahwa orangberpengaruh langsung dan sig- nifikan terhadap kepuasan pelanggan ditolak, memberikan penjelasan bahwa banyak faktor yang menyebabkan faktor orangtidak diperhitungkan atau dipertimbangkan untuk menjadi peserta Jamsostek. Mengingat program jamsostek merupakan suatu kewajiban, sehingga tidak ada pilihan bagi perusahaan untuk menolaknya.

Hasil pengujian pengaruh langsung proses terhadap kepuasan pelanggan secara statistik menunjukkan hasil yang tidak signifikan. Hal itu ditunjukkan oleh nilai CR sebesar -1.503 dan probabilitas signifikansi $(p)=0,133>\alpha=0,05$ mengindikasikan bahwa pengaruhnya tidak signifikan. Maka hipotesis yang menyatakan bahwa proses berpengaruh langsung dan signifikan terhadap kepuasan pelanggan ditolak, menjelaskan bahwa alur atau proses seperti pencairan klaim di Jamsostek sesuai dengan standart aturan yang sudah di tentukan sehingga oleh peserta Jamsostek tidak terlalu diperhatikan dan kurang di nilai.

Hasil pengujian pengaruh langsung bukti fisik terhadap kepuasan pelanggan secara statistik menunjukkan hasil yang signifikan. Hal itu ditunjukkan oleh nilai CR sebesar 3.077 dan probabilitas signifikansi $(p)=0,002<\alpha=0,05$ mengindikasikan bahwa pengaruhnya signifikan. Maka hipotesis yang menyatakan bahwa bukti fisik berpengaruh langsung dan signifikan terhadap kepuasan pelanggan diterima, sehingga memberikan penjelasan bahwa bukti fisik menjadi pertimbangan untuk menjadi peserta Jamsostek seperti gedung kantor, ruang tunggu dan desain fasilitas dengan memperlihatkan penampilan yang bagus dan indah.

Pengaruh kepuasan pelanggan terhadap komunikasi dari mulut ke mulut dapat di lihat pada tabel berikut:

Hasil pengujian pengaruh langsung kepuasan pelanggan terhadap komunikasi mulut ke mulut secara statistik menunjukkan hasil yang signifikan. Hal itu ditunjukkan oleh nilai CR sebesar 1.964

Tabel 3: Pengaruh kepuasan pelanggan terhadap komunikasi mulut ke mulut

\begin{tabular}{llllll}
\hline & & Estimate & S.E. & C.R. & P \\
\hline Komunikasi mulut ke mulut $(\mathrm{Y} 2)$ & $\leftarrow$ Kepuasan Pelanggan $(\mathrm{Y} 1)$ & 0.26 & 0.142 & 1.964 & 0.048 \\
\hline
\end{tabular}


dan probabilitas signifikansi $(p)=0,048<\mathrm{a}=0,05$ mengindikasikan bahwa pengaruhnya signifikan. Maka hipotesis yang menyatakan bahwa kepuasan pelanggan berpengaruh langsung dan signifikan terhadap komunikasi dari mulut ke mulut diterima. Besarnya nilai estimasi sebesar 0,26 menunjukkan besarnya perubahan komunikasi dari mulut kemulut (Y2) yang disebabkan perubahan variabel kepuasan pelanggan (Y1) dengan asumsi variabel yang lain konstan. Hal ini sejalan dengan penelitian yang dilakukan oleh Yang Xuecheng, di tahun 2008 yaitu peranan kepuasan terhadap WOM, dengan menggunakan pemasaran dan kepuasan sebagai varibel bebas dan WOM sebagai variabel terikatnya, diketahui bahwa usaha pemasaran memiliki pengaruh yang positif terhadap perilaku penyebaran WOM (Word of Mouth) pada pelanggan, dan kepuasan pelanggan memainkan sebuah peranan penting antara hubungan pemasaran dan perilaku WOM.

Hasil pengujian pengaruh langsung produkterhadap komunikasi mulut ke mulut secara statistik menunjukkan hasil yang signifikan. Hal itu ditunjukkan oleh nilai CR sebesar 2.186 dan probabilitas signifikansi $(p)=0,039>\alpha=0,05$ mengindikasikan bahwa pengaruhnya signifikan. Maka hipotesis yang menyatakan bahwa produkberpengaruh langsung dan signifikan terhadap komunikasi mulut ke mulut diterima. Besarnya nilai estimasi sebesar 0,209 menunjukkan besarnya perubahan komunikasi dari mulut ke mulut (Y2) yang disebabkan oleh perubahan variabel produk (X1) dengan asumsi variabel yang lain konstan.
Hasil pengujian pengaruh langsung harga terhadap komunikasi mulut ke mulut secara statistik menunjukkan hasil yang signifikan. Hal itu ditunjukkan oleh nilai CR sebesar 2.306 dan probabilitas signifikansi $(p)=0,21<\alpha=0,05$ mengindikasikan bahwa pengaruhnya signifikan. Maka hipotesis yang menyatakan bahwa harga berpengaruh langsung dan signifikan terhadap komunikasi mulut ke mulut diterima. Besarnya nilai estimasi sebesar 0,297 menunjukkan besarnya perubahan komunikasi mulut ke mulut $(\mathrm{Y})$ yang disebabkan oleh perubahan variabel hanga (X2) dengan asumsi variabel yang lain konstan. Besarnya nilai estimasi sebesar 0,297 menunjukkan besarnya perubahan komunikasi dari mulut ke mulut (Y2) yang disebabkan oleh perubahan variabel Harga (X2) dengan asumsi variabel yang lain konstan. Hasil pengujian pengaruh langsung tempat terhadap komunikasi mulut ke mulut secara statistik menunjukkan hasil yang signifikan. Hal itu ditunjukkan oleh nilai CR sebesar 3.009 dan probabilitas signifikansi $(p)=0,003<\alpha=$ 0,05 mengindikasikan bahwa pengaruhnya signifikan. Maka hipotesis yang menyatakan bahwa tempatberpengaruh langsung dan signifikan terhadap komunikasi mulut ke mulut diterima.

Besarnya nilai estimasi sebesar 0,373 menunjukkan besarnya perubahan komunikasi mulut ke mulut $(\mathrm{Y})$ yang disebabkan oleh perubahan variabel tempat(X3) dengan asumsi variabel yang lain konstan. Hasil pengujian pengaruh langsung promosi terhadap komunikasi mulut ke mulut secara statistik menunjukkan hasil yang tidak sig-

Tabel 4: Ringkasan Perhitungan bauran pemasaran Terhadap komunikasi mulut ke mulut

\begin{tabular}{lcccc}
\hline & Estimate & S.E. & C.R. & P \\
\hline WOM $\leftarrow$ Kepuasan pelanggan & .26 & .142 & 1.964 & .048 \\
WOM $\leftarrow$ Produk & .209 & .126 & 2.186 & .039 \\
WOM $\leftarrow$ Harga & .297 & .129 & 2.306 & .021 \\
WOM $\leftarrow$ Tempat & .373 & .124 & 3.009 & .003 \\
WOM $\leftarrow$ Promosi & .281 & .318 & .884 & .377 \\
WOM $\leftarrow$ Orang & -.018 & .095 & -.187 & .852 \\
WOM $\leftarrow$ Proses & .04 & .199 & .202 & .840 \\
WOM $\leftarrow$ Bukti fisik & -.091 & .102 & -.891 & .373 \\
\hline
\end{tabular}


nifikan. Hal itu ditunjukkan oleh nilai CR sebesar 0.884 dan probabilitas signifikansi $(p)=0,377<$ $\alpha=0,05$ mengindikasikan bahwa pengaruhnya tidak signifikan. Maka hipotesis yang menyatakan bahwa promosi berpengaruh langsung dan signifikan terhadap komunikasi mulut ke mulut ditolak. Ini menjelaskan bahwa media promosi yang bertujuan memperkenalkan tentang program Jamsostek tidak menimbulkan efek atau pengaruh untuk menularkan atau menceritakan kepada teman dan orang lain.

Hasil pengujian pengaruh langsung orang terhadap komunikasi mulut ke mulutsecara statistik menunjukkan hasil yang tidak signifikan. Hal itu ditunjukkan oleh nilai CR sebesar -0.187 dan probabilitas signifikansi $(p)=0,852>\alpha=$ 0,05 mengindikasikan bahwa pengaruhnya tidak signifikan. Maka hipotesis yang menyatakan bahwa orang berpengaruh langsung dan signifikan terhadap komunikasi mulut ke mulut ditolak. Ini memberikan penjelasan bahwa faktor orangtidak diperhitungkan atau dipertimbangkan oleh peserta untuk menceritakan program Jamsostek kepada peserta lainnya.

Hasil pengujian pengaruh langsung proses terhadap komunikasi mulut ke mulut secara statistik menunjukkan hasil yang tidak signifikan. Hal itu ditunjukkan oleh nilai CR sebesar 0.202 dan probabilitas signifikansi $(p)=0,840>\alpha=$ 0,05 mengindikasikan bahwa pengaruhnya tidak signifikan. Dengan demikian hipotesis yang menyatakan bahwa proses berpengaruh langsung dan signifikan terhadap komunikasi dari mulut ke mulut ditolak.

Hasil pengujian pengaruh langsung bukti fisik terhadap komunikasi mulut ke mulut secara statistik menunjukkan hasil yang tidak signifikan. Hal itu ditunjukkan oleh nilai CR sebesar -0.891 dan probabilitas signifikansi $(p)=0,373<\alpha=$ 0,05 mengindikasikan bahwa pengaruhnya tidak signifikan. Maka hipotesis yang menyatakan bahwa bukti fisik berpengaruh langsung dan signifikan terhadap komunikasi dari mulut ke mulut ditolak.

Pengaruh bauran pemasaran terhadap komunikasi dari mulut ke mulut melalui kepuasan pelanggan dapat dijelaskan merupakan pengaruh tidak langsung yang ditimbulkan oleh bauran pemasaran terhadap komunikasi dari mulut ke mulut karena pengaruh bauran pemasaran ini harus melalui variabel kepuasan pelanggan. Adapun hasil perhitungan yang telah dilakukan tertuang pada table sebagai berikut:

Tabel 5: Pengujian Pengaruh Variabel melalui kepuasan pelanggan

\begin{tabular}{lcccc}
\hline & Estimate & S.E. & C.R. & P \\
\hline WOM $\leftarrow$ Kepuasan pelanggan & .26 & .142 & 1.964 & .048 \\
WOM $\leftarrow$ Produk & .209 & .126 & 2.186 & .039 \\
WOM $\leftarrow$ Harga & .297 & .129 & 2.306 & .021 \\
WOM $\leftarrow$ Tempat & .373 & .124 & 3.009 & .003 \\
WOM $\leftarrow$ Promosi & .281 & .318 & .884 & .377 \\
WOM $\leftarrow$ Orang & -.018 & .095 & -.187 & .852 \\
WOM $\leftarrow$ Proses & .04 & .199 & .202 & .840 \\
WOM $\leftarrow$ Bukti fisik & -.091 & .102 & -.891 & .373 \\
\hline
\end{tabular}

Dari informasi yang disajikan, diketahui bahwa pengaruh bauran pemasaran yang terdiri dari produk, harga, tempat, promosi, orang, proses dan bukti fisik terhadap komunikasi mulut ke mulut secara umum memiliki pengaruh langsungyang lebih besar dari pengaruh tidak langsungnya, artinya kepuasan pelanggan tidak bersinergi dengan variabel marketing mix yang terdiri dari produk, harga, tempat, promosi, orang, proses dan bukti fisik. Hal ini dapat dijelaskan bahwa komunikasi 
dari mulut dari ke mulut secara umum seringkali dipengaruh oleh tingginya kinerja bauran pemasaran yang diterapkan oleh suatu perusahaan, dalam hal ini PT. Jamsostek (Persero).

Hasil dalam analisis ini menunjukan bahwa Bauran pemasaran yang terdiri dari produk, harga, tempat, promosi, orang, proses dan bukti fisik tidak memberikan pengaruh terhadap komunikasi dari mulut ke mulut (WOM) hal ini disebabkan pengaruh langsung yang lebih besar dari pengaruh tidak langsungnya, artinya kepuasan pelanggan tidak bersinergi dengan variabel bauran pemasaran yang terdiri dari produk, harga, tempat, promosi, orang, proses dan bukti fisik.

Berdasarkan hasil penelitian yang telah di lakukan dapat dijelaskan bahwa secara umum bauran pemasaran yang terdiri dari produk, harga, tempat, promosi, orang, proses dan bukti fisik memberikan pengaruh terhadap komunikasi dari mulut ke mulut baik secara langsung dan tidak langsung. Hal ini sejalan dengan penelitian yang dilakukan oleh Ekrem Cengiz (Turkey), Hilmi Erdogan Yayla (Turkey) di tahun 2007 bertujuan untuk mengetahui pengaruh 4p (produk, promosi, tempat dan harga) terhadap komunikasi dari mulut ke mulut pada pegawai akunting di Turkey. Meskipun pada pelaksanaan penelitian ini terdapat variabel-variabel yang berbeda pada penentuan bauran pemasaran dimana pada panelitian terdahulu hanya terdiri dari $4 \mathrm{p}$ sedangkan pada penelitian ini menambahkan tiga indikator dari bauran pemasaran yaitu orang, proses dan bukti fisik atau dikenal dengan $7 \mathrm{P}$.

Dari hasil pembahasan yang telah dilakukan diketahui bahwa dari bauran pemasaran yang terdiri dari tujuh indikator yaitu produk, harga, tempat, promosi, orang, proses dan bukti fisik tidak semuanya memiliki pengaruh secara signifikan terhadap kepuasan pelanggan dan komunikasi dari mulut ke mulut dimana variabel orang dan prosess tidak memberikan pengaruh yang berarti.

Kondisi pengaruh dari hasil penelitian ini memberikan penjelasan bahwa bauran pemasaran atau lazim disebut dengan tradisional marketing mix terdiri dari 4P (produk, harga, tempat, promosi)memberikan pengaruh signifikan. Hal ini sejalan dengan apa yang diungkapkan olehZeithaml dan Bitner (2000:18-21) mengemukakan konsep bauran pemasaran tradisional (traditional marketing mix) terdiri dari 4P, yaitu: Product (produk), Price (harga), Place (tempat/lokasi), dan Promotion (promosi) yang cenderung intangible (merupakan jasa) mendapatkan keyakinan penuh oleh para peserta Jamsostek bahwa keikutsertaan karena memahami betul karakteristik Product (produk), Price(harga), Place(tempat/lokasi), dan Promotion (promosi).

Sementara itu, untuk pemasaran jasa perlu bauran pemasaran yang di perluas (expanded marketing mix for service) dengan penambahan unsur non-traditional marketing mix, yaitu: People (orang), Process (proses) dan Physical Evidence (bukti fisik), sehingga menjadi unsur (7P). dalam penelitian ini belum sepenuhnya terbukti memberikan pengaruh secara signifikan secara keseluruhan, hanya saja bukti fisik (physical evidence) memberikan pengaruh yang signifikan, hal ini tidak terlepas dari lingkungan fisik di PT. Jamsostek (Persero) sebagai pemberi jasa yaitu memperlihatkan gedung kantor yang bagus dan indah, di samping itu juga sebagai sarana untuk meningkatkan kepercayaan kepada peserta terutama pada saat melakukan transaksi.

\section{SIMPULAN}

Berdasarkan hasil penelitian dan pembahasan dapat diambil kesimpulan sebagai berikut: 1).Bauran pemasaran yang terdiri dari produk, harga, tempat, promosi, orang, proses dan bukti fisik memberikan pengaruh terhadap kepuasan pelanggan pada peserta program Jamsostek, dengan rincian bahwa variabel produk, harga, tempat, promosi, orang, proses dan bukti fisik memberikan pengaruh signifikan terhadap kepuasanpclanggan. Ini sejalan dengan penelitian yang dilakukan oleh Zeithaml dan Bitner (2000:18-21). Sedangkan orang dan proses tidak memberikan pengaruh yang signifikan terhadap kepuasan pelanggan. 2). Kepuasan pelanggan memberikan pengaruh terhadap komunikasi dari mulut ke mulut (WOM) pada peserta program Jamsostek, sejalan dengan 
penelitian yang dilakukan oleh Yang Xuecheng, di tahun 2008. 3). Bauran pemasaran yang terdiri dari produk, harga, tempat, promosi, orang, proses dan bukti fisik memberikan pengaruh terhadap komunikasi mulut ke mulut (WOM) pada peserta program Jamsostek, sejalan dengan penelitian yang dilakukan Ekrem Cengiz (Turkey), Hilmi Erdogan Yayla (Turkey) di tahun 2007. 4).Bauran pemasaran yang terdiri dari produk, harga, tempat, promosi, orang, proses dan bukti fisik tidak memberikan pengaruh terhadap komunikasi mulut ke mulut (WOM) hal ini disebabkan pengaruh langsung yang lebih besar dari pengaruh tidak langsungnya, artinya kepuasan pelanggan tidak bersinergi dengan variabel bauran pemasaran yang terdiri dari produk, harga, tempat, promosi, orang, proses dan bukti fisik.

Mengacu pada hasil penelitian terhadap bauran pemasaran dengan menggunakan variabel $7 \mathrm{p}$ hanya $5 \mathrm{p}$ yang memberikan pengaruh signifikan terhadap kepuasan pelanggan. Variabel bauran pemasaran 5p tersebut yaitu: produk, hanga, tempat, promosi, dan bukti fisik, sementara varibel $2 \mathrm{p}$ yang tidak memberikan pengaruh signifikan terhadap kepuasan pelanggan yaitu: orang dan proses. Dengan demikian, di sarankan PT. Jamsostek (Persero) Kantor Cabang Pasuruan lebih memperhatikan variabel tersebut agar peserta program Jamsostek bertambah meningkat perbaikan seperti dengan mengadakan pelatihan-pelatihan yang bertujuan meningkatkan sumber daya manusia serta mengidentifikasi kembali tentang alur/ proses dengan cara menghapus prosedur yang sekiranya tidak di perlukan. Hal ini di sampaikan agar memberikan dampak yang positif, karena dalam penelitian ini variabel bauran pemasaran $7 \mathrm{p}$ yaitu: produk, harga, tempat, promosi, orang, proses dan bukti fisik memberikan pengaruh signifikan baik secara langsung maupun tidak langsung terhadap komunikasi dari mulut ke mulut (WOM). Maksudnya apabila variabel bauran pemasaran positif maka akan menimbulkan komunikasi dari mulut ke mulut yang positif sehingga akan menguntungkan perusahaan tetapi apabila variabel bauran pemasaran negatif maka akan menimbulkan komunikasi dari mulut ke mulut yang negatif dan merugikan perusahaan.
Bagi peneliti selanjutnya, hendaknya melakukan penelitian lebih lanjut dengan menjadikan hasil penelitian ini sebagai pedoman khususnya pada penemuan teori-teori yang berhubungan dengan bauran pemasaran, kepuasan pelanggan dan strategi komunikasi dari mulut ke mulut, sehingga ilmu pengetahuan yang berhubungan dengan bauran pemasaran, kepuasan pelanggan dan komunikasi dari mulut ke mulut (WOM) dapat lebih berkembang lagi. Selain itu juga di harapkan dapat menambah variabel-variabel baru dengan menggunakan analisis yang berbeda.

\section{DAFTARPUSTAKA}

Assauri, Sofyan, 1999. Manajemen Pemasaran Dasar dan Konsep Strategi. Jakarta: PT Raja Grafindo.

Ekrem Cengiz (Turkey), Hilmi Erdogan Yayla (Turkey) (2007), The effect of marketing mix on positive word of mouth communication: evidence from accounting offices in Turkey. Innovative Marketing, Volume 3, Issue 4, 2007

Erida, "Pengaruh Kepuasan Terhadap Perilaku WOM (Word-Of-Mouth)”. Magister Sain, Manajemen Pemasaran, Jurusan Manajemen Fakultas Ekonomi Universitas Jambi.

Hasan, Ali, 2010. Marketing dari Mulut ke Mulut, Yogyakarta: Media Pressindo,

Johannes, Mulyadi Raf, M. Lukman, Analisis Kepuasan Nasabah Prioritas Berdasarkan Bauran Pemasaran (Kasus Pada PT. Bank Central Asia, Tbk Kantor Cabang Utama Jambi). Journal of Management and Marketing Research

Kotler, Philip, 1996. Manajemen Pemasaran Jilid 1 Analsis, Perencanaan, Implementasi, dan Pengendalian. Jakarta: Erlangga

-____——, 1997. Manajemen Pemasaran di Indonesia (terjemahan $A B$. Susanto). Jakarta: Salemba Empat. $\mathrm{dkk}, 1994$. manjemen Pemasaran Persepektif Asia. Yogyakarta: ANDI OFFSET 
Lupiyoadi, Rambat, 2001. Manajemen Pemasaran Jasa Teori dan Praktek. Jakarta: Salemba Empat.

Moenir, HAS, 1995. Manajemen Pelayanan Umum Indonesia. Jakarta: Bumi Aksara

Purwoko, Bambang, 2003. Ventura (Jurnal Ekonomi Bisnis dan Akuntansi) Vol. 6, No. 1. Surabaya: PPPM STIE PERBANAS SURABAYA

Rangkuti, Freddy, 2003. Measuring Costumer Satisfaction. Jakarta: PT SUN

Setyawati, Indah. Analisis Pengaruh Kualitas

Layanan Dan Kepuasan Pasien Terhadap

Words Of Mouth. Jurnal manajemen Program

Pascasarjana Universitas Diponegoro

Semarang.

Sitepu, SK, Nirwana, 1994. Analisis Jalur (Path Analysis). Bandung: Unit Pelayanan Statsistik, FMIPA Universitas Padjajaran.

Sugiyono, 2000. Statistika untuk Penelitian. Bandung: CV.ALFABETA

Swastha, Basu, 2000. Asas-Asas Marketing. Yogyakarta: Liberty. \& Irawan, 1998. Manajemen Pemasaran Modern. Yogyakarta: Liberty. , dkk.1998. Pengantar Bisnis

Modern. Yogyakarta: Liberty.
Stanton, J William, 1997. Prinsip Pemasaran (Edisi terjemahan oleh Sanduru) Edisi tujuh Jilid I. Jakarta: Erlangga.

Sudikin \& Mundir. 2005. Metode Penelitian: Membimbing dan Mengantar Kesuksesan Anda dalam Dunia Penelitian. Insan Cendikia: Surabaya

Suharsimi, Arikunto. 2002. Penelitian, Suatu Pendekatan Praktek, Jakakarta: Bina Aksara

Tjiptono, Fandy, 2002. Manajemen Jasa. Yogyakarta:ANDI OFFSET

——_———, 2002. Strategi Pemasaran. Yogyakarta:ANDI OFFSET

- —————, 2000. Perspektip Manajamen dan Pemasaran Kontemporer. Yogyakarta: ANDI OFFSET.

Valarie A Zeithaml \& Mary Jo Bitner, Service Marketing, Integrating Customer Focus Across The firm. Second edition

Yang Xuecheng, 2008, Impact of Marketing Efforts and Customer Satisfaction on Wordof-Mouth - - Study Based on Mobile Phone Users in China. School of Economics and Management, Beijing University of Posts and Telecommunications Beijing, 100876, China 